\title{
In vitro stimulation of metacyclogenesis in Leishmania braziliensis, L. donovani, L. major and L. mexicana
}

\author{
H. A. ZAKAI $\uparrow$, M. L. CHANCE and P. A. BATES* \\ Liverpool School of Tropical Medicine, Pembroke Place, Liverpool L3 5QA
}

(Received 28 Fuly 1997; revised 1 November 1997; accepted 11 November 1997)

\begin{abstract}
SUMMARY
Promastigotes of Leishmania braziliensis, L. donovani, L. major and L. mexicana recently derived from tissue amastigotes were cultured in Schneider's Drosophila medium supplemented with $20 \%$ (v/v) heat-inactivated foetal calf serum and 25 $\mu \mathrm{g}$ gentamicin sulfate $/ \mathrm{ml}$ at $\mathrm{pH} 5 \cdot 5$. These cultures produced more metacyclic promastigotes in their stationary-phase populations than others cultured at $\mathrm{pH} 7 \cdot 0$. Metacyclic promastigotes possessed a short $(\leqslant 8 \mu \mathrm{m})$ and narrow $(\leqslant 1 \cdot 5 \mu \mathrm{m})$ cell body with a flagellum twice or more the length of the cell body. Promastigotes from acidic cultures were more resistant to complement-mediated lysis and more infective in vivo than those grown at neutral $\mathrm{pH}$. These results demonstrate that induction of metacyclogenesis by acidic $\mathrm{pH}$ is a response conserved across a variety of species of Leishmania.
\end{abstract}

Key words: Leishmania spp., promastigote, metacyclic, culture, infectivity, differentiation.

\section{INTRODUCTION}

Parasites of the genus Leishmania adopt 2 main morphological forms during their life-cycle; the amastigote, which divides within cells of the vertebrate host, and various types of promastigote, which are found in the gut lumen of the sandfly.

Early investigators believed that there was 1 particular form of promastigote in the sandfly which was adapted for life in the vertebrate host, now known as the metacyclic promastigote (Shortt, Smith \& Swaminath, 1931; Adler \& Ber, 1941). More recently, morphological and biochemical differences between dividing midgut forms and those found anteriorly in sandflies have been recognized, and many workers have investigated metacyclic forms and metacyclogenesis (see for example, KillickKendrick, 1990; Bates, 1994).

In a previous study, metacyclogenesis in $L$. mexicana was induced by culturing promastigotes at acidic pH (Bates \& Tetley, 1993). The metacyclic promastigotes produced were resistant to complement-mediated lysis and were highly infective to macrophages in vitro. In this present study, we have extended this investigation of metacyclogenesis to include species causing different types of clinical disease: L. braziliensis, L. donovani, L. major and $L$. mexicana. Metacyclic promastigotes and multiplicative promastigotes of these 4 species were characterized in terms of morphology, complement resistance and infectivity in vivo.

* Corresponding author. Tel: 0151708 9393. Fax: 0151 708 9007. E-mail: pbates@liverpool.ac.uk.

\section{MATERIALS AND METHODS}

\section{Parasites}

Infections of L. donovani (MHOM/ET/67/HU3; LV9) and L. braziliensis (MHOM/BR/84/LTB300) were maintained in hamsters. L. mexicana (MNYC/ BZ/62/M379) and L. major clone FV-1 (MHOM/ $\mathrm{IL} / 80 /$ Friedlin) infections were maintained in $\mathrm{BALB} / \mathrm{c}$ mice. Promastigotes were obtained by transformation of tissue amastigotes at $26^{\circ} \mathrm{C}$ in HO-MEM (Berens, Brun \& Krassner, 1976) supplemented with $10 \%(\mathrm{v} / \mathrm{v})$ heat-inactivated foetal calf serum (FCS) and $25 \mu \mathrm{g}$ gentamicin sulfate $/ \mathrm{ml}$, followed by culture for 2-4 days. Recently transformed promastigotes were subcultured into Schneider's Drosophila medium (Life Technologies) supplemented with $20 \%(\mathrm{v} / \mathrm{v})$ heat-inactivated FCS and $25 \mu \mathrm{g}$ gentamicin sulfate $/ \mathrm{ml}$ at $26^{\circ} \mathrm{C}$. The initial $\mathrm{pH}$ of this medium was adjusted either to $7 \cdot 0$ or $5 \cdot 5$ using $1 \mathrm{M} \mathrm{HCl}$ or $1 \mathrm{M} \mathrm{NaOH}$ as required and $10 \mathrm{ml}$ volumes were cultured in $25 \mathrm{~cm}^{2}$ tissue culture flasks using air as the gas phase. Cell counting was performed using an Improved Neubauer haemocytometer under phase-contrast microscopy.

\section{Light microscopy}

Thin smears were prepared from promastigotes, air dried, fixed in absolute methanol, and stained for 10 min in $10 \%(\mathrm{v} / \mathrm{v})$ Giemsa's stain in $10 \mathrm{~mm}$ sodium phosphate buffer $(\mathrm{pH} 7 \cdot 2)$. Slides were examined at $\times 1000$ magnification under oil immersion. Measurements were made using an Olympus microscope fitted with a drawing tube. A ruler and a test slide 
were used to calibrate the microscope so that each 2 $\mu \mathrm{m}$ on the test slide was equal to $1 \mathrm{~mm}$ on the ruler. Cell body length $(L)$ and width $(W)$ were measured for a minimum of 100 promastigotes in each slide examined.

\section{Complement-mediated lysis}

Promastigotes in the exponential phase or stationary phase (first day where there was no increase in cell density) of growth in vitro were harvested by centrifugation and washed in Hanks' balanced salt solution (HBSS) twice, then resuspended to a density of $10^{7}$ cells $/ \mathrm{ml}$ in HO-MEM supplemented with $10 \%(\mathrm{v} / \mathrm{v})$ heat-inactivated FCS, pH 7.0. Doubling dilutions of guinea-pig serum from $1: 1$ to $1: 128$ were prepared in the same medium in 96 -well flat-bottom plates, in a volume of $100 \mu \mathrm{l} / \mathrm{well}$. Promastigote suspensions were added $(100 \mu \mathrm{l})$, the plate was covered with Parafilm and incubated at 26 ${ }^{\circ} \mathrm{C}$ for $1 \mathrm{~h}$. At the end of the incubation period, $40 \mu \mathrm{l}$ of $50 \mathrm{~mm}$ EDTA were added (final concentration $8 \cdot 3$ $\mathrm{mm})$, to stop complement-mediated lysis. Examination was performed by pipetting $5 \mu \mathrm{l}$ volumes on a glass slide and covering with a $22 \times 22 \mathrm{~mm}$ coverslip. In this way, promastigotes were trapped between the slide and the cover-slip and movements of viable promastigotes were easily observed. Viability was estimated for each serum dilution by examining 100 promastigotes and determining the percentage with moving flagella. The concentration of serum that lysed $50 \%$ of promastigotes was used to compare relative resistance of different cultures to complement-mediated lysis.

\section{Infectivity in vivo}

Stationary-phase promastigotes cultured at $\mathrm{pH} 7 \cdot 0$ and 5.5 were washed twice in HBSS and brought to a density of $1 \times 10^{8}$ cells $/ \mathrm{ml}$ for $L$. donovani, $2 \times 10^{7}$ cells $/ \mathrm{ml}$ for $L$. mexicana and L. major and $4 \times 10^{8}$ cells $/ \mathrm{ml}$ for L. braziliensis. Two groups of 12 female $\mathrm{BALB} / \mathrm{c}$ mice were used for each species, one was inoculated with promastigotes cultured at $\mathrm{pH} 7 \cdot 0$ and the other with promastigotes cultured at $\mathrm{pH} 5 \cdot 5$.

Mice to be infected with $L$. donovani were inoculated i.v. in the tail vein with $0.2 \mathrm{ml}$ containing $2 \times 10^{7}$ promastigotes and killed 2 weeks after inoculation. Their livers were removed and impression smears made after weighing. Smears were fixed in absolute methanol for $1 \mathrm{~min}$, stained in $10 \%$ (v/v) Giemsa/phosphate buffer for 25-30 min and examined under the microscope. A magnification of $\times 400$ was used to find an area on the slide with a uniform layer of hepatocyte nuclei. Amastigotes were counted /1000 liver cell nuclei at $\times 1000$ magnification. The mean number of amastigotes/ liver cell nucleus was multiplied by the weight of the liver (mg) to obtain the LDU (Leishman-Donovan units) index of infectivity (Bradley \& Kirkley, 1977). A $t$-test of significance was used to compare statistically the LDU values using the Minitab program.

Mice to be inoculated with L. mexicana, L. major and L. braziliensis were shaved at the base of the tail and inoculated subcutaneously at this site with 0.05 $\mathrm{ml}$ containing $10^{6}$ promastigotes for L. mexicana and L. major and $2 \times 10^{7}$ promastigotes for L. braziliensis. Length and width of lesions were measured weekly with calipers for 10 weeks and the lesion size determined.

\section{RESULTS}

\section{Light microscopy}

Thin smears were made from exponential- and stationary-phase promastigotes cultured at $\mathrm{pH} 7 \cdot 0$ or 5.5 and examined. The value of $L \times W$ was calculated for each promastigote and any having a value of $\leqslant$ 12 was considered a culture-derived metacyclic promastigote. Such metacyclic promastigotes possessed short $(\leqslant 8 \mu \mathrm{m})$, narrow $(\leqslant 1.5 \mu \mathrm{m})$ cell bodies and long flagella twice or more the length of the cell body. Metacyclic promastigotes first appeared in acidic cultures during the exponential phase and reached prevalences of $77 \%$ for L. donovani, $78 \%$ for L. mexicana, $75 \%$ for L. major and $49 \%$ for $L$. braziliensis by the stationary phase (Fig. 1). The percentages of metacyclic promastigotes in equivalent stationary-phase cultures initiated at $\mathrm{pH} \mathrm{7 \cdot 0}$ were $11 \%$ for L. donovani, $29 \%$ for L. mexicana, $10 \%$ for L. major and $12 \%$ for L. braziliensis.

\section{Complement resistance}

Exponential- and stationary-phase promastigotes grown at acidic and neutral $\mathrm{pH}$ were subjected to complement-mediated lysis. The percentage of viable promastigotes was estimated using movement of the flagellum as a sign of viability. Stationary-phase promastigotes cultured at acidic $\mathrm{pH}$ showed a higher resistance to complement-mediated lysis than those grown in neutral $\mathrm{pH}$ (Table 1) in all 4 of the species tested, although each showed different relative resistance to complement-mediated lysis. To enable comparison between species, the concentration of serum required to cause $50 \%$ lysis in acidic and neutral cultures was expressed as a ratio, indicating 4 -fold to 16-fold increases in resistance.

\section{Infectivity in vivo}

Stationary-phase promastigotes of L. donovani cultured at $\mathrm{pH} 7 \cdot 0$ and 5.5 were used to infect 2 groups of 12 female BALB/c mice. Mice were killed 2 weeks after inoculation, their livers removed and the LDU determined for each. Out of 12 mice inoculated with promastigotes cultured at $\mathrm{pH} 5 \cdot 5,11$ had amastigotes 


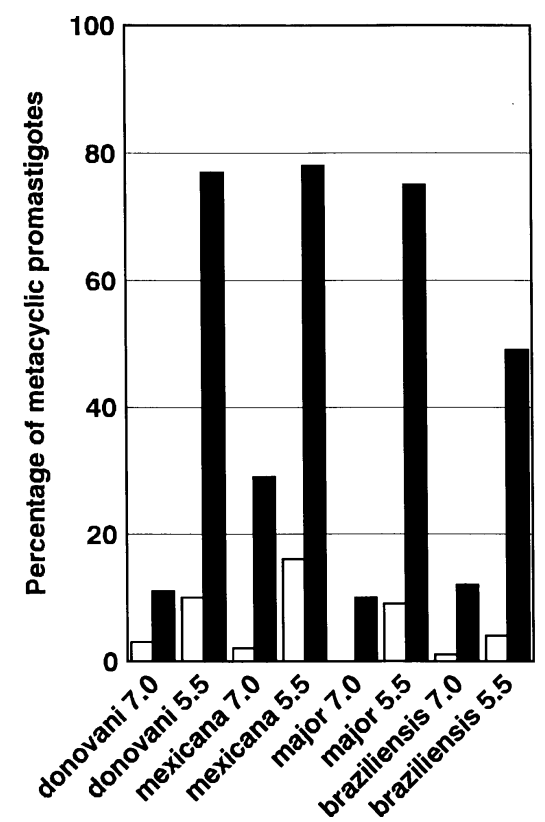

Fig. 1. Percentage of metacyclic promastigotes in exponential phase $(\square)$ and stationary phase ( $\square$ ) for cultures of Leishmania donovani, L. mexicana, L. major and L. braziliensis at $\mathrm{pH} 7 \cdot 0$ and $5 \cdot 5$.

Table 1. Relationship between culture $\mathrm{pH}$ and complement resistance of stationary-phase promastigotes

\begin{tabular}{|c|c|c|c|}
\hline Species & $\begin{array}{l}\text { pH of } \\
\text { culture }\end{array}$ & $\begin{array}{l}\text { Percentage } \\
\text { serum } \\
\text { causing } \\
50 \% \text { cell } \\
\text { lysis }\end{array}$ & $\begin{array}{l}\text { Increase in } \\
\text { resistance }\end{array}$ \\
\hline $\begin{array}{c}\text { Leishmania } \\
\text { donovani }\end{array}$ & $\begin{array}{l}7 \cdot 2 \\
5 \cdot 5\end{array}$ & $\begin{array}{l}6 \cdot 25 \\
25\end{array}$ & 4-fold \\
\hline $\begin{array}{c}\text { Leishmania } \\
\text { mexicana }\end{array}$ & $\begin{array}{l}7 \cdot 2 \\
5 \cdot 5\end{array}$ & $\begin{array}{l}1 \cdot 56 \\
12 \cdot 5\end{array}$ & 8 -fold \\
\hline $\begin{array}{l}\text { Leishmania } \\
\text { major }\end{array}$ & $\begin{array}{l}7 \cdot 2 \\
5 \cdot 5\end{array}$ & $\begin{array}{l}3 \cdot 125 \\
50\end{array}$ & 16-fold \\
\hline $\begin{array}{l}\text { Leishmania } \\
\text { braziliensis }\end{array}$ & $\begin{array}{l}7 \cdot 2 \\
5 \cdot 5\end{array}$ & $\begin{array}{l}0 \cdot 78 \\
3 \cdot 125\end{array}$ & 8 -fold \\
\hline
\end{tabular}

of $L$. donovani in their livers and the average LDU in this group was 276 ( \pm 54 s.E.). On the other hand, only 3 out of 12 mice inoculated with promastigotes cultured at $\mathrm{pH} 7 \cdot 0$ had amastigote infections with an average LDU of $14 \cdot 1( \pm 7 \cdot 4$ s.E.) in this group. The LDU values were compared using a $t$-test, which indicated a significant statistical difference between the 2 values $(P=0 \cdot 0007)$. This clearly indicated that promastigotes cultured at acidic $\mathrm{pH}$ were more infective than those cultured at neutral $\mathrm{pH}$. In other words, mice infected with promastigotes cultured in acidic $\mathrm{pH}$ had approximately $5 \cdot 5 \times 10^{7}$ amastigotes/

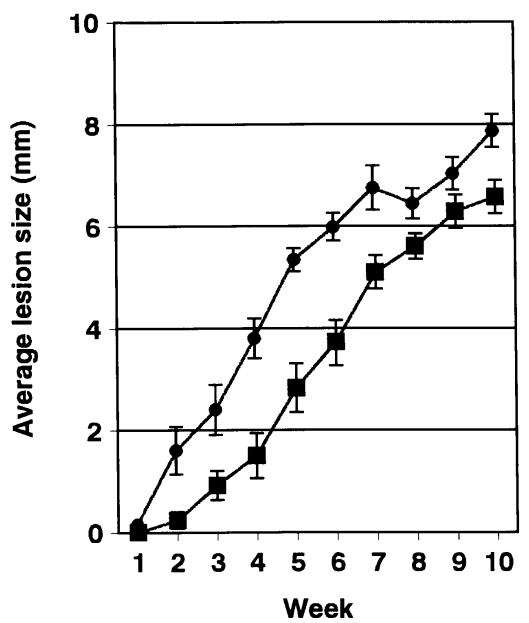

Fig. 2. Development of Leishmania mexicana lesions in $\mathrm{BALB} / \mathrm{c}$ mice infected with stationary-phase promastigotes cultured at $\mathrm{pH} 7 \cdot 0(\mathbf{\square})$ and $5 \cdot 5$

(- Each group contained 12 animals. The bars represent 1 standard error of the mean.

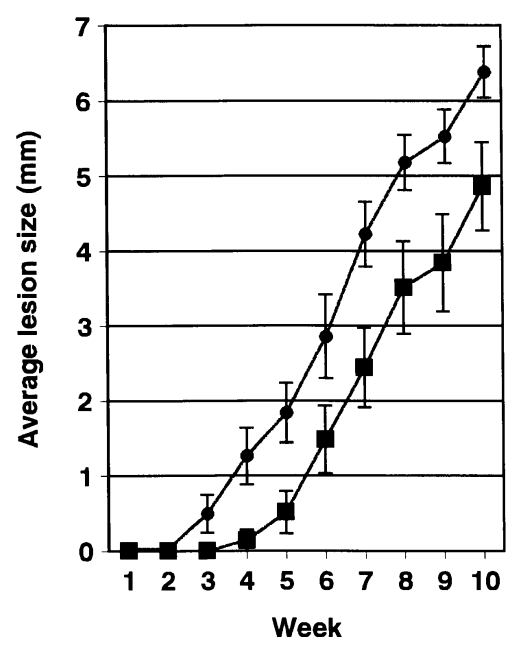

Fig. 3. Development of Leishmania major lesions in $\mathrm{BALB} / \mathrm{c}$ mice infected with stationary-phase promastigotes cultured at $\mathrm{pH} 7 \cdot 0$ (口- $\mathbf{\square}$ ) and $5 \cdot 5$ (- Each group contained 12 animals. The bars represent 1 standard error of the mean.

liver while those infected with promastigotes cultured at $\mathrm{pH} 7 \cdot 0$ had approximately $2 \cdot 8 \times 10^{6}$ amastigotes/liver.

Stationary-phase promastigotes of $L$. mexicana, $L$. major and L. braziliensis cultured at $\mathrm{pH} 7.0$ and 5.5 were used to infect 2 groups of $12 \mathrm{BALB} / \mathrm{c}$ mice for each species. Mice were examined once a week for 10 weeks and the sizes of cutaneous lesions were measured. In all groups for each of the 3 species, lesion development and size was faster in mice inoculated with promastigotes cultured at $\mathrm{pH} 5 \cdot 5$ than in those inoculated with promastigotes cultured at $\mathrm{pH} 7 \cdot 0$ (Figs 2-4). In the case of L. mexicana and L. major, a superficial, non-ulcerating papule appeared first. This developed into a nodule with a 


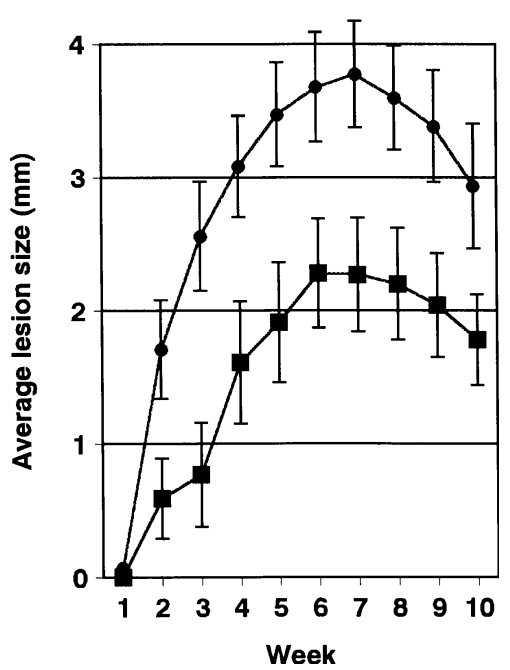

Fig. 4. Development of Leishmania braziliensis lesions in $\mathrm{BALB} / \mathrm{c}$ mice infected with stationary-phase promastigotes cultured at $\mathrm{pH} 7 \cdot 0$ (口- $\square$ ) and $5 \cdot 5$ (-) Each group contained 12 animals. The bars represent 1 standard error of the mean.

larger border and deeper centre. A few mice inoculated with L. major had centrally ulcerated nodules during the last 2 weeks of the experiment. In the case of L. braziliensis, lesions appeared as small hairless patches of rough skin at the site of inoculation. Even though such lesions were not very distinctive, they were larger and their appearance was earlier in mice inoculated with promastigotes cultured at $\mathrm{pH} 5 \cdot 5$ compared to mice inoculated with promastigotes cultured at $\mathrm{pH} 7 \cdot 0$.

\section{DISCUSSION}

When cultures of Leishmania promastigotes reach stationary phase, a proportion of the population may differentiate into metacyclic promastigotes (Sacks, 1989). This proportion depends upon, amongst other factors, the length of time the promastigotes have been maintained in vitro (da Silva \& Sacks, 1987). In a previous study, we showed that cultivation of recently transformed (2-4 days) L. mexicana promastigotes in Schneider's Drosophila medium supplemented with $20 \%$ heat-inactivated FCS at acidic $\mathrm{pH}$ produced a homogeneous stationary-phase population of metacyclic-like promastigotes. However, cultivation of such promastigotes to stationary phase at $\mathrm{pH} 7 \cdot 0$ yielded a mixed population of metacyclic and other forms (Bates \& Tetley, 1993).

In this study we were able to stimulate metacyclogenesis in promastigotes of L. braziliensis, $L$. donovani, and L. major using similar methodology. Culture-derived metacyclic promastigotes were defined by possession of a short $(\leqslant 8 \mu \mathrm{m})$, narrow ( $\leqslant$ $1.5 \mu \mathrm{m})$ cell body and a long flagellum twice or more the length of the cell body. These metacyclic promastigotes appeared as early as day 2 during the exponential phase in acidic cultures ( $\mathrm{pH} 5 \cdot 5)$ and by the stationary phase, $49-78 \%$ of promastigotes were metacyclic forms, depending on the species. In contrast, only 10-29\% of promastigotes cultured originally at $\mathrm{pH} 7 \cdot 0$ differentiated to metacyclic promastigotes by the stationary phase. Although the percentage of metacyclic promastigotes produced varied between the different species, consistency in producing similar percentages of metacyclic promastigotes was achieved in repeated experiments (not shown). However, we cannot exclude strain as opposed to species differences as a factor in the variation observed.

One of the defence components of the mammalian host against parasitic protozoa is the complement system. Therefore, for promastigotes to be able to establish a Leishmania infection, they have to be resistant to complement-mediated lysis. Metacyclic promastigotes are not only resistant to complementmediated lysis, but in addition they use complement components as ligands for binding and entry into macrophages (Alexander \& Russell, 1992). In this study stationary-phase promastigotes grown in acidic $\mathrm{pH}$ were more resistant to complement-mediated lysis than those grown at neutral pH. A 4 to 16 -fold increase in resistance was observed among the 4 Leishmania species studied. This is consistent with previous reports of metacyclogenesis in vitro (Franke et al. 1985; Howard, Sayers \& Miles, 1987; Wozencraft \& Blackwell, 1987; Bandyopadhyay et al. 1991, Almeida et al. 1993; Bates \& Tetley, 1993).

Another criterion that has been used to characterize metacyclic promastigotes is their infectivity in vivo. Leishmania parasites have been shown to infect several models (reviewed by Hommel et al. 1995), although none of these models completely accurately reproduces what happens in humans. In this study $\mathrm{BALB} / \mathrm{c}$ mice were used to investigate the difference between the infectivity of stationary-phase $L$. donovani promastigotes cultured at $\mathrm{pH} 5.5$ and those cultured at $\mathrm{pH} 7 \cdot 0$. Two weeks after inoculation, there was a statistically significant difference between the 2 types of inocula. Metacyclic promastigotes obtained from the stationary phase of acidic cultures were approximately 20 times more infective than promastigotes obtained in the stationary phase from neutral cultures.

With L. mexicana and L. major, and using the same inoculum size, mice infected with stationaryphase promastigotes from acidic cultures developed cutaneous lesions earlier than those infected with stationary-phase promastigotes from neutral cultures. The sizes of lesions increased consistently as the experiment progressed. When the average lesion diameter was plotted against time the standard error bar of the 2 curves never overlapped. This demonstrated that the lesion development in one group was consistently greater than that of the other group.

L. braziliensis lesions appeared as small hairless rough skin at the site of inoculation, even though a 
larger inoculum was used. However, the sizes of lesions were larger and their appearance was earlier in mice inoculated with promastigotes cultured at pH $5 \cdot 5$.

In this study we have used acidic conditions to stimulate metacyclogenesis in vitro. Whether this also occurs in vivo is a matter for speculation, but 2 observations suggest that it may do so. During growth in vitro promastigotes are normally seen to acidify the culture medium in which they are growing. The densities in such cultures are $10^{7}-10^{8}$ cells $/ \mathrm{ml}$. In vivo promastigotes can achieve very high densities within the sandfly midgut, forming a solid mass of parasites embedded in a gel-like matrix in the anterior midgut, something equivalent to $10^{9}-$ $10^{10}$ cells $/ \mathrm{ml}$. Thus it seems quite possible that this density of parasites could case a fall in $\mathrm{pH}$. The second observation is some recent measurements of $\mathrm{pH}$ in the gut of Lutzomyia longipalpis (Tang, Anez \& Bates, 1997), which found a neutral to slightly acidic $\mathrm{pH}$ in the anterior midgut, compared to a more alkaline $\mathrm{pH}$ in the posterior midgut. These studies were performed on uninfected sandflies only, as thus far it has proved technically difficult to perform the same experiments on infected flies.

In conclusion, this study has shown that it is possible to stimulate the production of metacycliclike promastigotes of $L$. braziliensis, L. donovani, $L$. major and L. mexicana in vitro by culturing at $\mathrm{pH}$ $5 \cdot 5$.

This work was supported by a Ph.D. studentship to H.A.Z. from King Abdulaziz University, Jeddah, Saudi Arabia. The technical assistance of D. Reynolds is gratefully acknowledged.

\section{REFERENCES}

ADLER, S. \& BER, M. (1941). The transmission of Leishmania tropica by the bite of Phlebotomus papatasi. Indian Fournal of Medical Research 29, 803-809.

AlEXANDER, J. \& RUSSELl, D. G. (1992). The interaction of Leishmania species with macrophages. Advances in Parasitology 31, 175-254.

Almeida, M. C., CUba, C. A. C., SA, C. M., Pharoah, M. M., HOWARD, K. M. \& MILES, M. A. (1993). Metacyclogenesis of Leishmania (Viannia) braziliensis in vitro: evidence that lentil lectin is a marker of complement resistance and enhanced infectivity. Transactions of the Royal Society of Tropical Medicine and Hygiene 87, 325-329. Bandyopadhyay, P., GHOSH, D. K., DE, A., GHOSH, K. N., CHAUdhURI, P. P., DAs, P. \& BHATTACHARYA, A. (1991). Metacyclogenesis of Leishmania spp.: species-specific in vitro transformation, complement resistance, and cell surface carbohydrate and protein profiles. Fournal of Parasitology 77, 411-416.

Bates, P. A. (1994). The developmental biology of Leishmania promastigotes. Experimental Parasitology 79, 215-218.

BATES, P. A. \& TETLEY, L. (1993). Leishmania mexicana: induction of metacyclogenesis by cultivation of promastigotes at acidic pH. Experimental Parasitology 76, 412-423.

BERENS, R. L., BRUN, R. \& KRASSNER, S. M. (1976). A simple monophasic medium for axenic cultivation of hemoflagellates. Fournal of Parasitology 62, 360-365.

BRADLEY, D. J. \& KIRKLEY, J. (1977). Regulation of Leishmania populations within the host. I. The variable course of Leishmania donovani infections in mice. Clinical and Experimental Immunology 30, 119-129.

DA SILVA, R. \& SACKS, D. (1987). Metacyclogenesis is a major determinant of Leishmania promastigote virulence and attenuation. Infection and Immunity 55, 2802-2806.

FRANKe, E. D., McGReEvy, P. B., KATZ, S. P. \& SACKs, D. L. (1985). Growth cycle-dependent generation of complement-resistant Leishmania promastigotes. Fournal of Immunology 134, 2713-2718.

HOMMel, M., JAFFe, C. L., TRAVI, B. \& MilON, G. (1995). Experimental models for leishmaniasis and for testing anti-leishmanial vaccines. Annals of Tropical Medicine and Parasitology 89 (Suppl. 1), 55-73.

HOWARD, M. K., SAYERS, G. \& MILES, M. A. (1987).

Leishmania donovani metacyclic promastigotes: transformation in vitro, lectin agglutination, complement resistance, and infectivity. Experimental Parasitology 64, 147-156.

KILLICK-KENDRICK, R. (1990). The life-cycle of Leishmania in the sandfly with special reference to the form infective to the vertebrate host. Parasitologie Humaine et Comparée 65, 37-42.

SACKS, D. L. (1989). Metacyclogenesis in Leishmania promastigotes. Experimental Parasitology 89, 101-103.

SHORTT, H. E., SMITH, R. O. A. \& SWAMINATH, C. s. (1931). Transmission of Indian kala-azar by the bite of Phlebotomus argentipes. Indian Fournal of Medical Research 18, 1373-1375.

TANG, Y., ANEZ, N. \& BATES, P. A. (1997). A simple technique for measuring the $\mathrm{pH}$ of the gut contents in Lutzomyia longipalpis (Psychodidae: Diptera) by microcapillary feeding of a $\mathrm{pH}$ indicator, Phenol Red, into the gut lumen of the flies. Endemic Disease Bulletin (in the Press).

WOZENCRAFT, A. O. \& BLACKWELL, J. M. (1987). Increased infectivity of stationary-phase promastigotes of Leishmania donovani: correlation with enhanced C3 binding capacity and CR3-mediated attachment to host macrophages. Immunology 60, 559-563. 